\title{
Celebration's Urban Environment, Sustainable by the Joy of Living
}

\author{
Adilson Costa Macedo \\ Department of Architecture and Urbanism, University São Judas, São Paulo 03166000, Brazil
}

\begin{abstract}
Besides arguments like fighting against dispersed urbanization, improving economies of infrastructure and preserving natural resources, another measure to sustainability is the delight of people in staying together with others sharing a well-designed urban landscape. Analyzing the Celebration's urban setting is highlighted how some design firms are turning to reclaim the types of urbanism and traditional American architecture, representing the wish for reinforcing the daily vicinity relationships. As a matter of sustainability, it mentioned aspects of vehicular accessibility and the population density which is higher in Celebration than that in other suburban towns in USA. Attention is given both to the management of natural landscape and the role of the entrepreneur to construct a town in a so fragile soil. The relationship between community and sustainability is highlighted, leading to the idea of building spaces to become places, capable to convey the feeling of joy of living.
\end{abstract}

Key words: Smart growth, new urbanism, sustainable design, city architecture, urban design.

\section{Preliminary Assumptions}

Studying the project of the twenty years old Town of Celebration with a critical glance on today's reality, there come up some elements linked with concerns about urban planning in the United States of America. In the first place, the fight against dispersed urbanization which is a process of land occupation occurs also in other countries of the Americas. This is a worrying fact due to the current need to improve the economy of infrastructure, the preservation of natural resources and social relations between institutions and people. Could then, these facts be understood together to the aspirations of many architects and urban designers (representing major offices in USA), that are claiming to redesign patterns of urbanism and traditional American architecture? At Celebration, attention is drawn to the elements related to the natural landscape, the saving of technical resources and the leap to revise the traditional architecture. These facts can be put as the voice of urban designers entering the field of sustainability through the bias of redesigning

Corresponding author: Adilson Costa Macedo, Ph.D., professor, research fields: urban morphology, urban design. old-type spaces. Due to the high quality of the projects, spaces today are appropriated by the people in a positive way, with air of sustainable urban environment by the joy of living, as suggested by the title of this paper.

Going forward in the analysis of the Celebration project calls attention the elements related to the natural landscape and the technical resources required to deal with this so peculiar region. Another critical issue which refers to the good result of the design and should be valued is the role of the entrepreneur and its involvement in the implementation process. The ways of implement the project will be clarified through the text.

The text is based on bibliography referring to New Urbanism and Sustainability, in notes and recent articles published by the Internet and mainly in the knowledge of the place by the author. Like one architect with the belief that the urban fabric of the city must be viewed walking on foot, with eyes turned towards the analysis of the types of spaces-how people appropriate them-and the urban designer's eyes, as if he were about to develop a new project. 


\section{Celebration as a Real Setting}

Celebration is a new town in the State of Florida opened in 1996, located in the Osceola County, eastern portion of the state. It belongs to the metropolitan area of Orlando, city that polarizes a set of suburban locations very close to each other. Orlando is a center of intense commercial activity, hotels and conventions, services and housing. Centrality is enhanced by the presence of International Airport, Disney theme parks, International Convention Center, Universal Studio, Doctor Phillips and others. Adjacent to the theme parks are areas for housing and their amenities, each with its own characteristics having the town of Celebration incorporated to them 20 years ago.

It stands out as a planned neighborhood, of radial configuration, unlike some other small cities of the region that follow the linear pattern. At Celebration outskirts, there is a significant amount of office spaces occupied by related Walt Disney Group firms, besides a hospital of regional scope and a university campus. The existing North-South, Route 417, which runs through the city of Kissimmee serves as support for trade and services not found in Celebration. Particularly there are hotels that serve both Celebration and visitors to Disney World Park (Orlando 230,000; Kissimmee 15,000 population) (Fig. 1).

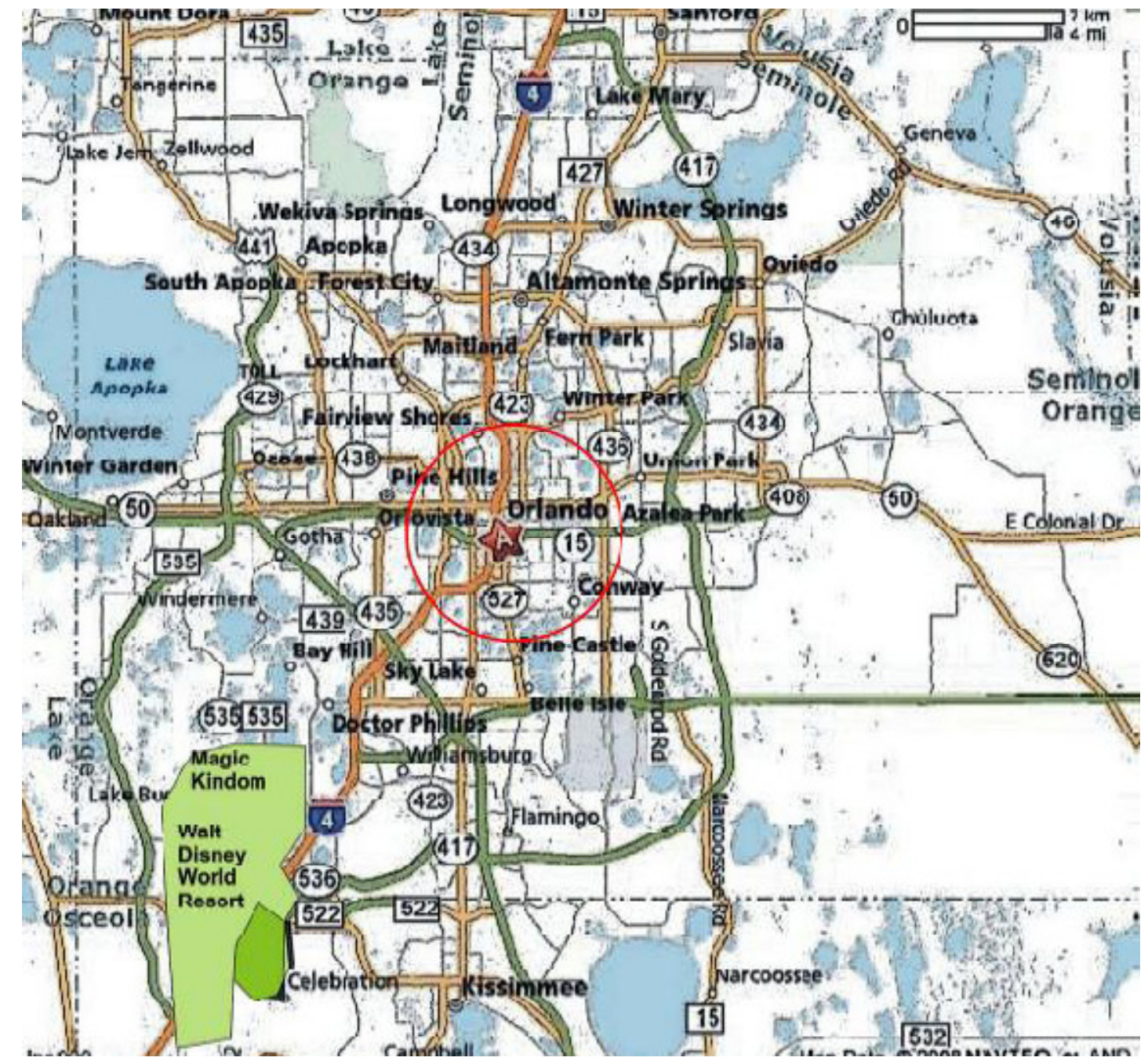

Fig. 1 Celebration, Disney resort and Orlando. Source: author's highlight, Mapquest 2016. 
Fig. 1 shows the counties boundaries: to the North, Orange and Seminole; West, Orange-Lake; East, Orange; South, Orange-Osceola. The Interstate 4 intersects this area of Florida in transverse direction, between the two main highways that link Miami to the north of the country: I-75 along the Gulf of Mexico coast on the west and follows the route I-95 alongside Atlantic Ocean.

The surface of the City of Celebration is 4,940 acres, of which 24.7 acres are aquifer reserves. Today the urbanized area accounts for about 50 percent of the total, with a population of 7,427 (2010). The expected population for this initial stage is 12,000 . The total population may reach 20,000 , resulting in the gross population density of 25 inhabitants per acre. The first residents arrived Celebration in October 1996. Nowadays it is considered that 40 percent of the population are individuals employed at Disney or related by family ties. This proportion is expected to decrease in the process of expansion of the city, when the demand for housing by families linked to Disney companies stabilizes. Another positive factor related to the population increment and the city development is the incremental interest of families for living in Celebration given to the high quality of the school system offered. Besides this fact, a plenty of people are choosing this place to have a second home, to spend their holidays [1].

The access traffic system is made by the Interstate I4 and the US192 that articulate with other local roads in the Orlando region. Through these parkway routes, the city connects with the International Airport (15 mile) and with the city center of Orlando (10 mile) heading north. The general distribution of collective, individual and cargo transportation is done by these parkways that articulate the accesses to the cities and districts. The City of Celebration is an urban landmark on World Drive, which is responsible for the main North-South connection: access to Disneyworld parks and theme parks. The 5-mile World Drive route connects Celebration with the Magic Kingdom landmark area at the Northern end of this road. There is an easy access between Celebration and the City of Kissimmee, a former Northeastern Florida town (Fig. 1).

\section{The Local Context}

From North to South:

- The space between routes US192 and US417 is planned as a corporative sector.

Headquarters of enterprises and institutional buildings such as the Celebration Regional Hospital were built in this area.

- The Golf Park Drive running East-West, parallel to US471, establishes a green reserve between them.

- The Celebration Golf Club was settled over there and its main entrance is located as a visual landmark. This point relates to straight view and an amazing boulevard (channel and side lanes) to the Town Center (signalized by a circle in Fig. 2).

Celebration is located off the freeway (I-4 and US192), having its own access flap from the US417 (Fig. 1), the Celebration Boulevard. This is a pattern of deployment recommended by the Urban Land Institute and American Planning Association, with the recognition of the Federal Transit Department, being in accordance with the Transit Oriented Development, TOD, principles as developed by Calthorpe and Fulton [2].

City limits are defined by the dashed line (Fig. 3). The routes I-4 and US-192 make regional interconnections. Local distribution of traffic takes place through US417 and the local access is through route I-4, the Celebration Boulevard. The internal main roads are articulated with Celebration Boulevard through the northwest-southeast axis. There is room for connections of new local roads when the city grows to the Southwest.

Downtown area is designed as those of the traditional American cities: recognized by Market Street, plus components coming from modern needs: individual vehicles, parking lots, energy points for the NEV, Neighborhood Electrical Vehicle (Fig. 4). 


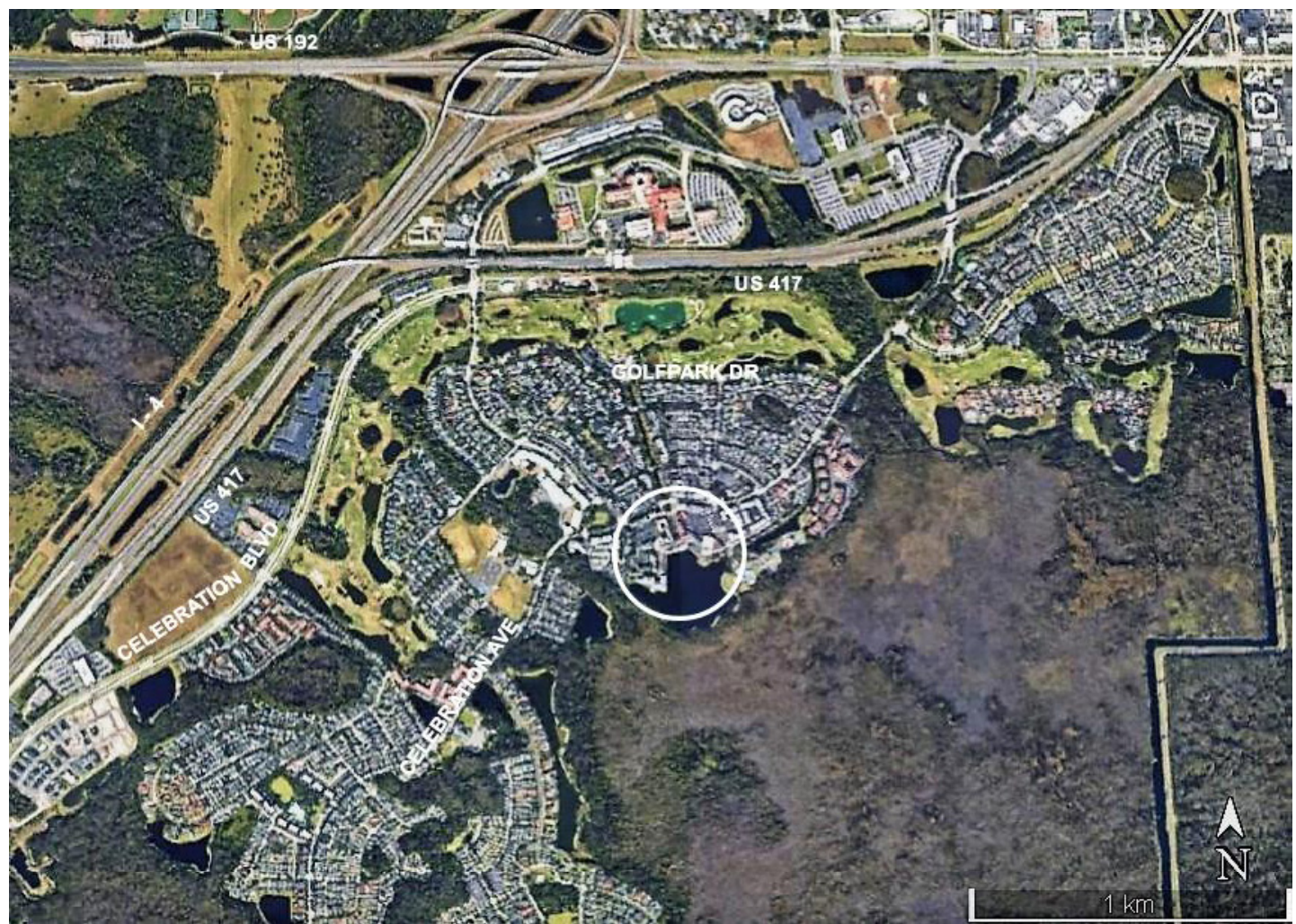

Fig. 2 Aerial view. Source: author's highlight, Google Earth 28.05.2017.

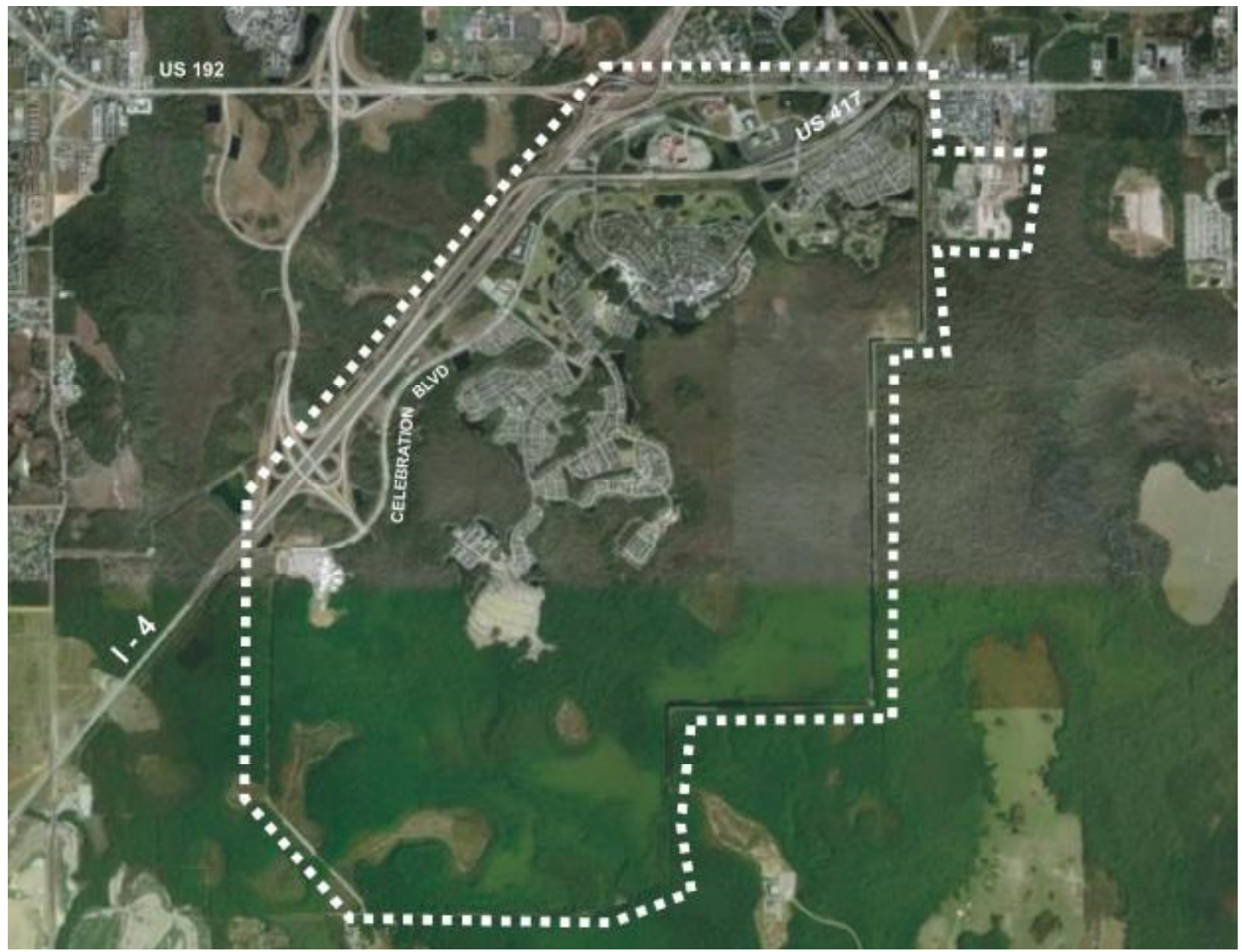

Fig. 3 Celebration, accessibility and site boundaries. Source: author, Google Earth 12.11.2010. 


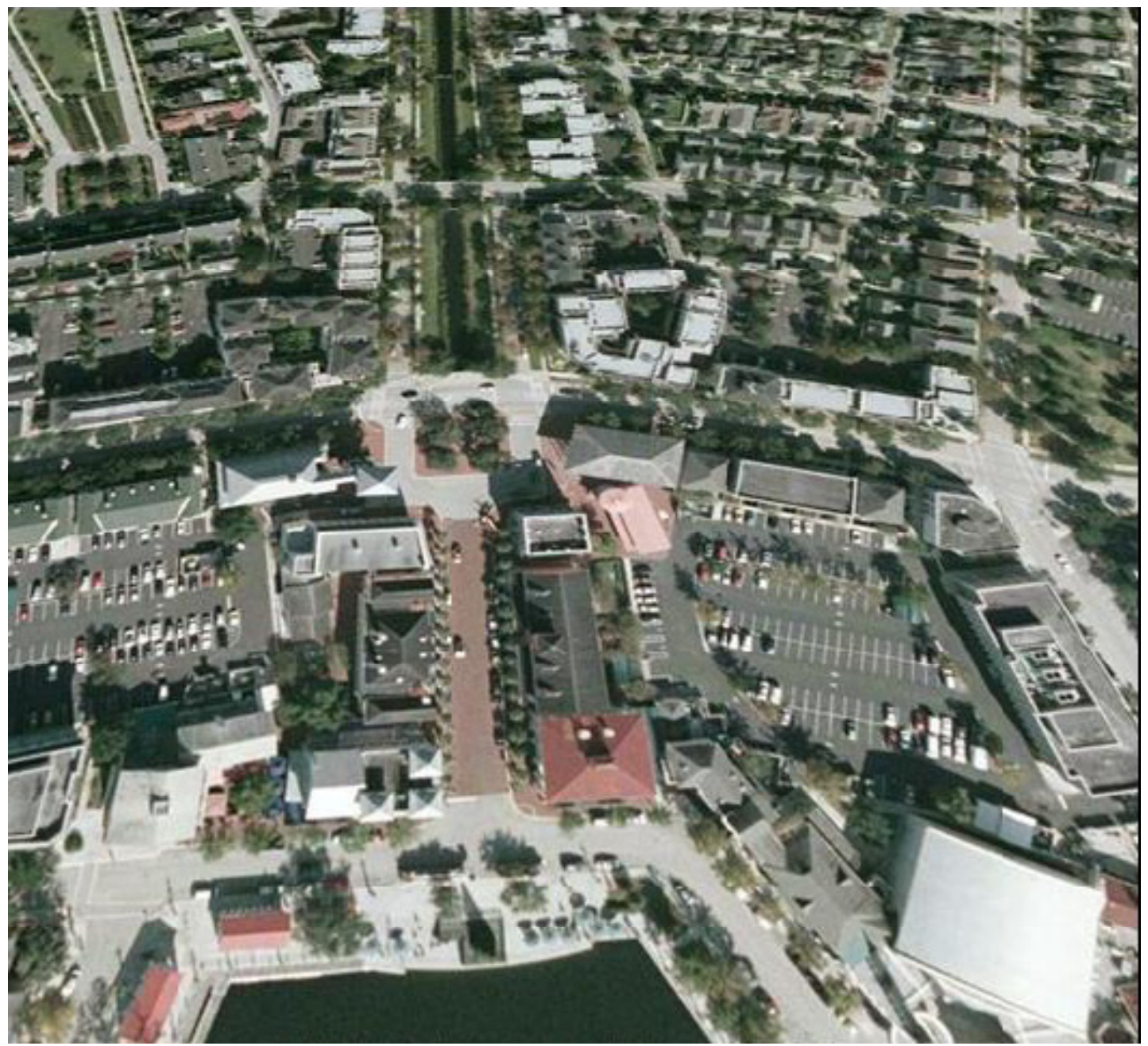

Fig. 4 Downtown area, Market Street, lake side deck, hidden parking areas. Source: Google Earth 27.05.2017.

City administration is an autonomous entity with respect to its initial incorporator, the Disney Group. It remains in the category of an unincorporated community. There is only one local Council of Representatives where the needs of the residents are discussed, which processes the community's demands by bringing them municipal power [3].

The focus of attention and the investigation in this paper refer mainly to the physical form of the city with emphasis in its main area. The citation of types of residential buildings is indicative of the diversity used in the projects and is related to American society and culture [4]. They deserve attention and deepening through specific research into the full understanding of the "traditional American city" and its redesign by New Urbanism of which Celebration is a vibrant sample.

\section{The Master Plan}

Master plan was designed by the firm of architects Cooper, Robertson \& Partners, CR \& P. The detail for the main area was the responsibility of Robert A. M. Stern Architects, RAMSA. Urban Design Associates, UDA, was hired for the development of the design guidelines for residential areas. The main entrepreneur was the Walt Disney Company through the subsidiary - the Celebration Company. The team of technicians, particularly architects, landscape architects, environmentalists, engineers for water resources, energy, transportation and infrastructure in general were professional's familiar with Disney theme parks and green preservation areas. The company, in the administrative-financial world, is a reference of 
organizational quality and interpersonal relationship (in the Company and with the public) being known for the high quality in the service rendering. This entrepreneur profile was reflected in the control of the plan development, whose implementation process has been criticized for being strongly attached in Disney's management. Disney as an entertainment company aims to "delight and keep its guests", has a controlled business posture in front of the investment plan and great demand for quality in everything it does, particularly in this $\$ 2.5$ billion-dollar project [5].

To understand Celebration's master plan, it was considered what those responsible wrote, beginning with CR \& P, then by RAMSA, and UDA.

CR \& P worked in the general plan, in articulation with the infrastructure projects, was responsible for the discussion process with the entrepreneur and real estate agents and developed several architectural projects contracted by the Celebration Company between 1987 and 1997. The explanations on this work are summarized as: "the plan was structured according to existing fields, forests and natural drainage paths. This allows a sense of permanence for the new streets, buildings and open spaces, the impression of always having been located there" (Fig. 5) [6].

In the design of the masterplan the zoning was represented by colors of different shades. They represent different types of housing and spaces for business, services and community support.

RAMSA was a partner in designing the plan and responsible for the development of the Downtown Celebration project. The following summary refers to the plan and design principles for the core area:

- Design based on the physical structure and sense of place like the traditional Southeast cities.

- Situate the center facing the lake and green area at the background.

- The residential neighborhoods radiate from the Center in streets of elongated and slightly curved blocks.

- Facilitate visitor's orientation through paths in a varied sequence of visuals (Fig. 6).

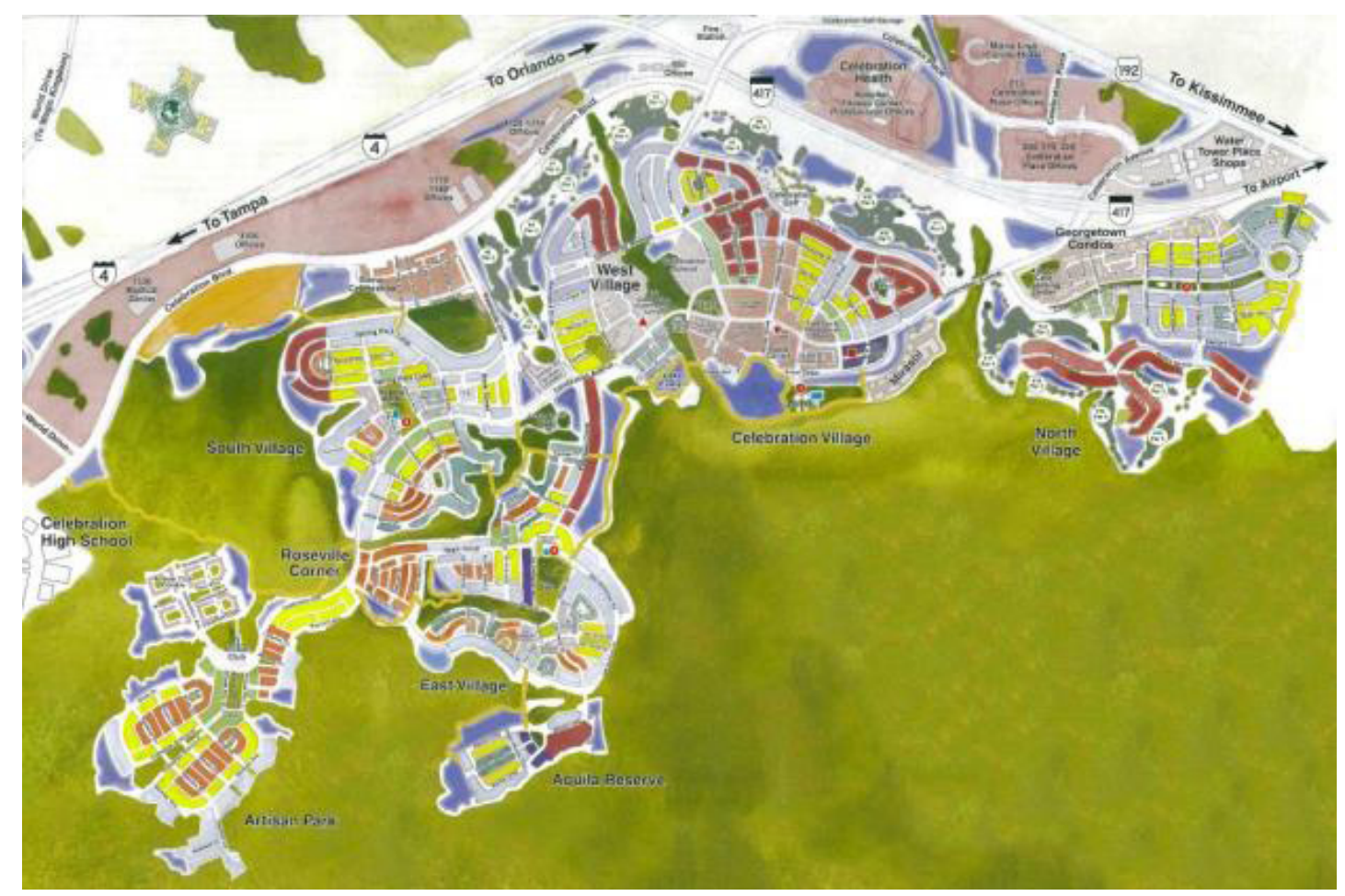

Fig. 5 Celebration master plan. Source: Memory Book flyer, 2010. 


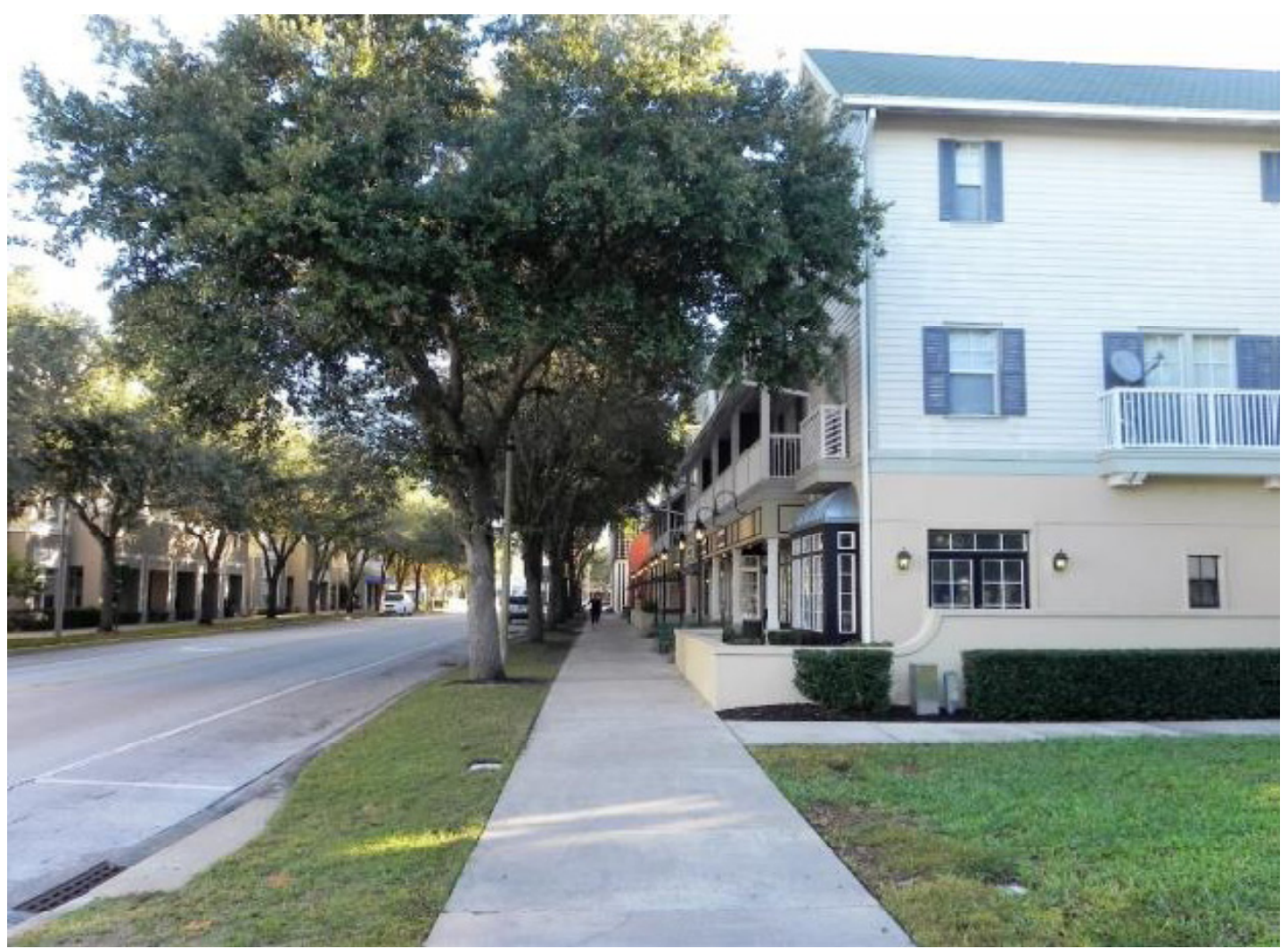

Fig. 6 Neighborhood character. Source: author, 13.01.2014.

- Place the stores occupying the front of the blocks in a continuous way, with the walk along the showcases protected by covered galleries (loggia). Possible by the above edification in the alignment of the lots and destined for the dwelling or offices.

- Design garages accessible by narrow paths at the bottom of the lots, leaving the front of the houses free with balconies of the traditional type (back to Fig. 4).

- Offer a variety of types of houses and prices, typical of a real city, as opposed to the homogeneity of suburban condos.

- The Center's buildings were designed for strengthening Celebration's character as a southeastern city of the country (Fig. 7).

- Design small-sized lots, organized in a row along the street and forming blocks, to increase occupancy density and optimize the use of urban infrastructure.

- To value the space of sidewalks by the leafy wings, in continuity with the parks and public buildings.

- To give public spaces a strong character, as one sensitive ingredient in reviewing the traditional styles.
- End the look of the streets in parks, streams or in nature reserves (Fig. 8).

To fulfill the points highlighted by RAMSA, it is good to remember that they believe the key buildings for an urban development such as Celebration must be signed by leading architectural firms. In this case there were selected architects, who have their names related to the New Urbanism and the Postmodern Architecture. Not only to ensure project quality, more for assisting in the enterprise marketing.

UDA, explains the design used for residential projects and from there is a summary of the result.

The Celebration Pattern Book indicates a set of principles for organizing spaces of collective use in residential areas and building types.

The first type of building is that of individual detached dwelling, but there are also twinned houses, townhouses and apartment buildings separated by green areas.

- Since Celebration is a community proposed to house different income classes, the design guidelines 


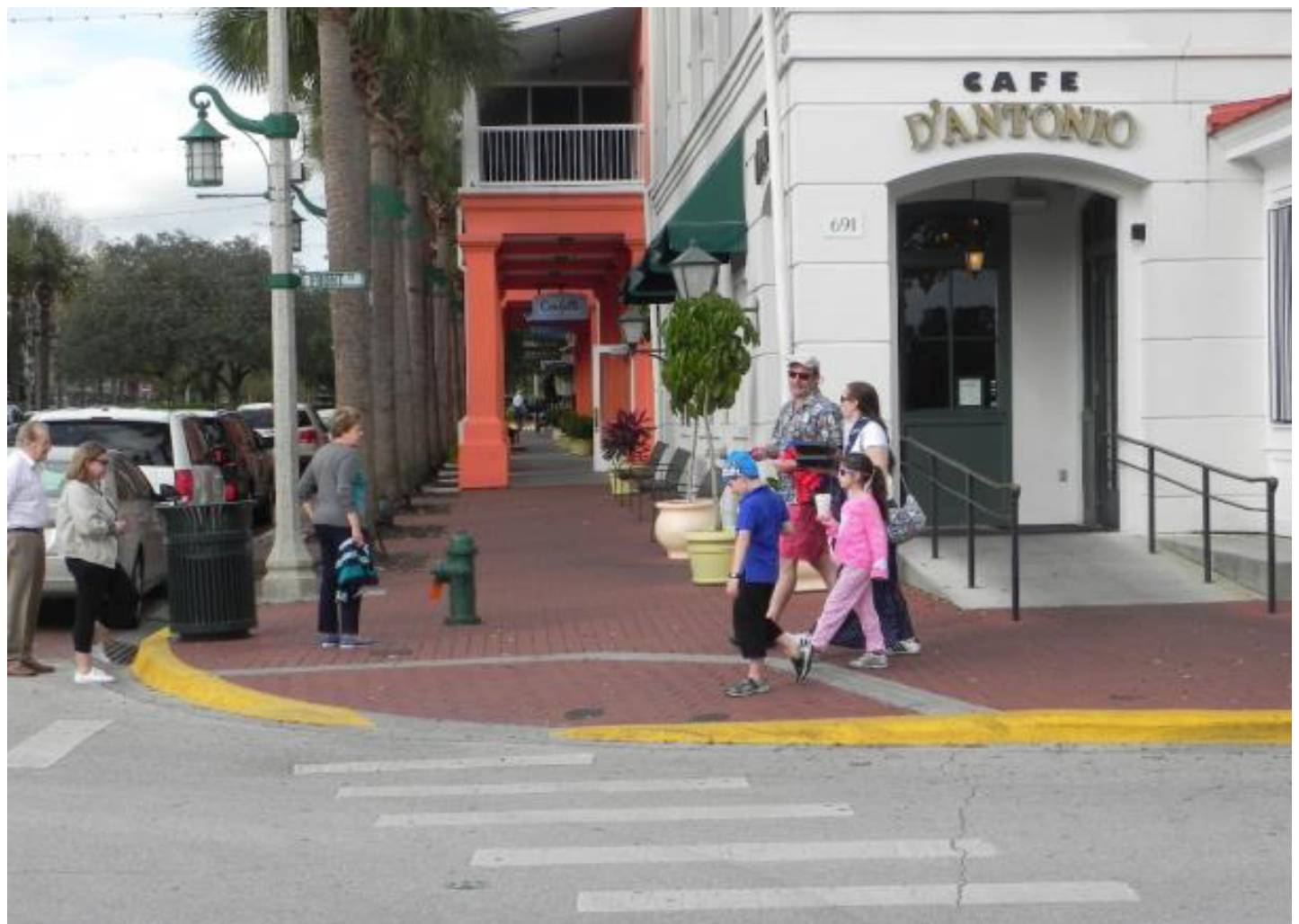

Fig. 7 A feeling of traditional city core. Source: author, 13.01.2014.

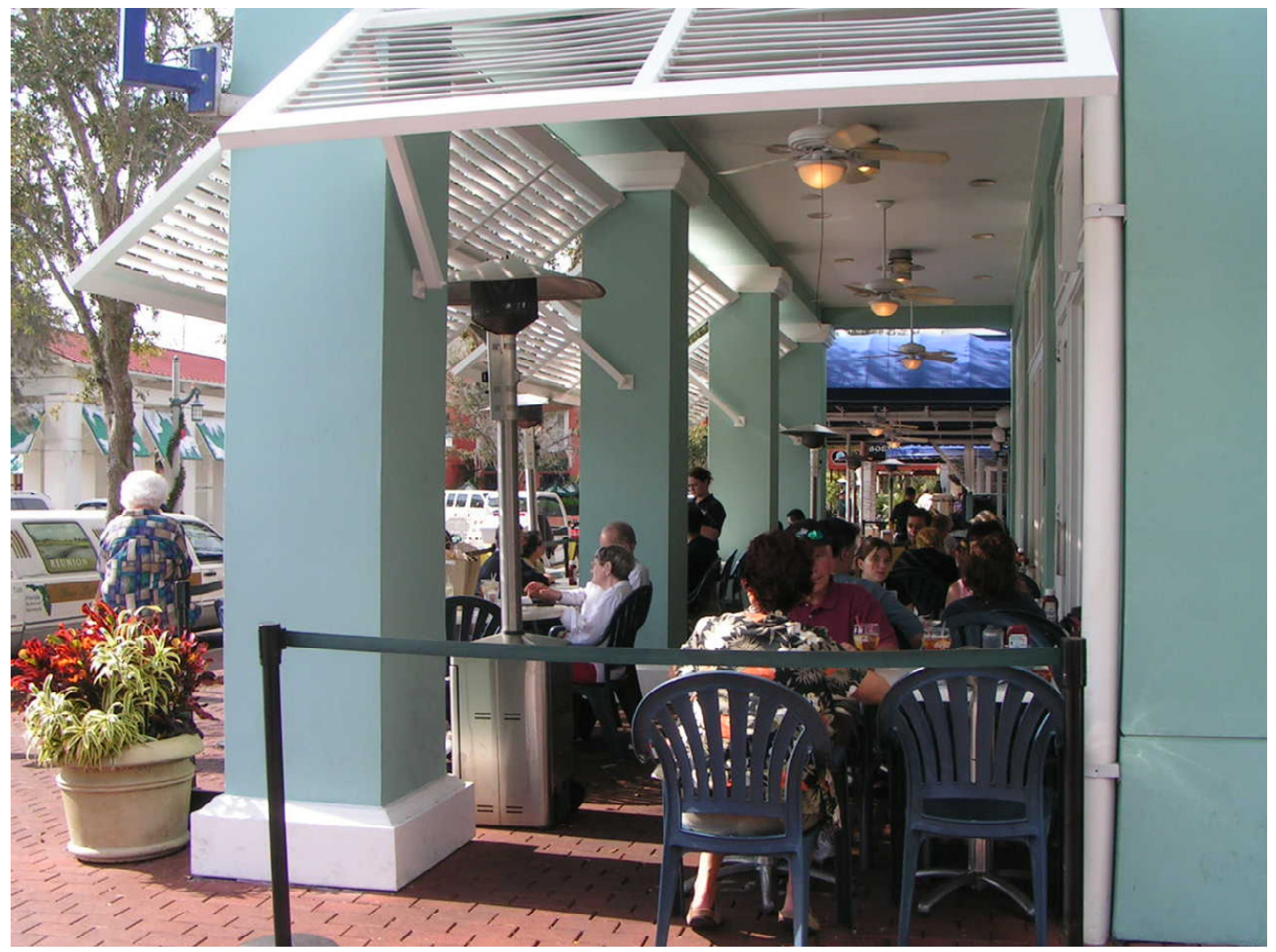

Fig. 8 The corner of market street facing the lake. Source: author 13.01.2014. 
emphasize the elements with which a harmonious relationship between varied sizes and styles can be found.

- The purpose of the Pattern Book is to be a reference for residential projects, where the guidelines are shaped in the style of those that the builders used in the US until World War II.

- Unlike the conventional code that limits the possibilities for entrepreneurs, the Pattern Book offers a collection of details and methods for constructing buildings and free spaces.

- It contains a set of useful information for the design of residential units according to the character of traditional neighborhoods [4]. Townhouses are an example, a classical type of grouping residences (Fig. 9).

The townhouse type appears in the Memory Book, the real estate advertising leaflet released in 1998 under the name of townhome, being an appeal for the sense of "home" associated with the property that the family would acquire. The Memory Book seeks to convey the climate of living in a small traditional town with balconies overlooking the street, low fences and children being able to call their little friends to play in the neighboring house (Fig. 10).

For dissemination purposes, the city is described in the Memory Book highlighting the types of housing, from the bungalow to the estate house. The pattern picking process appears on the UDA website and shows how the types were chosen for Celebration. Given their interest for professional practice and didactic objectives the method is described:

- Start with the search of spaces for collective use and the buildings of traditional cities.

- Visit different cities of traditional urban fabric, photograph and document collective spaces, typical solutions of buildings and their styles.

- Select the types, from the beginning 16 to Celebration and chosen six in the first phase of the implantation: Classical, Victorian, Colonial Revival,

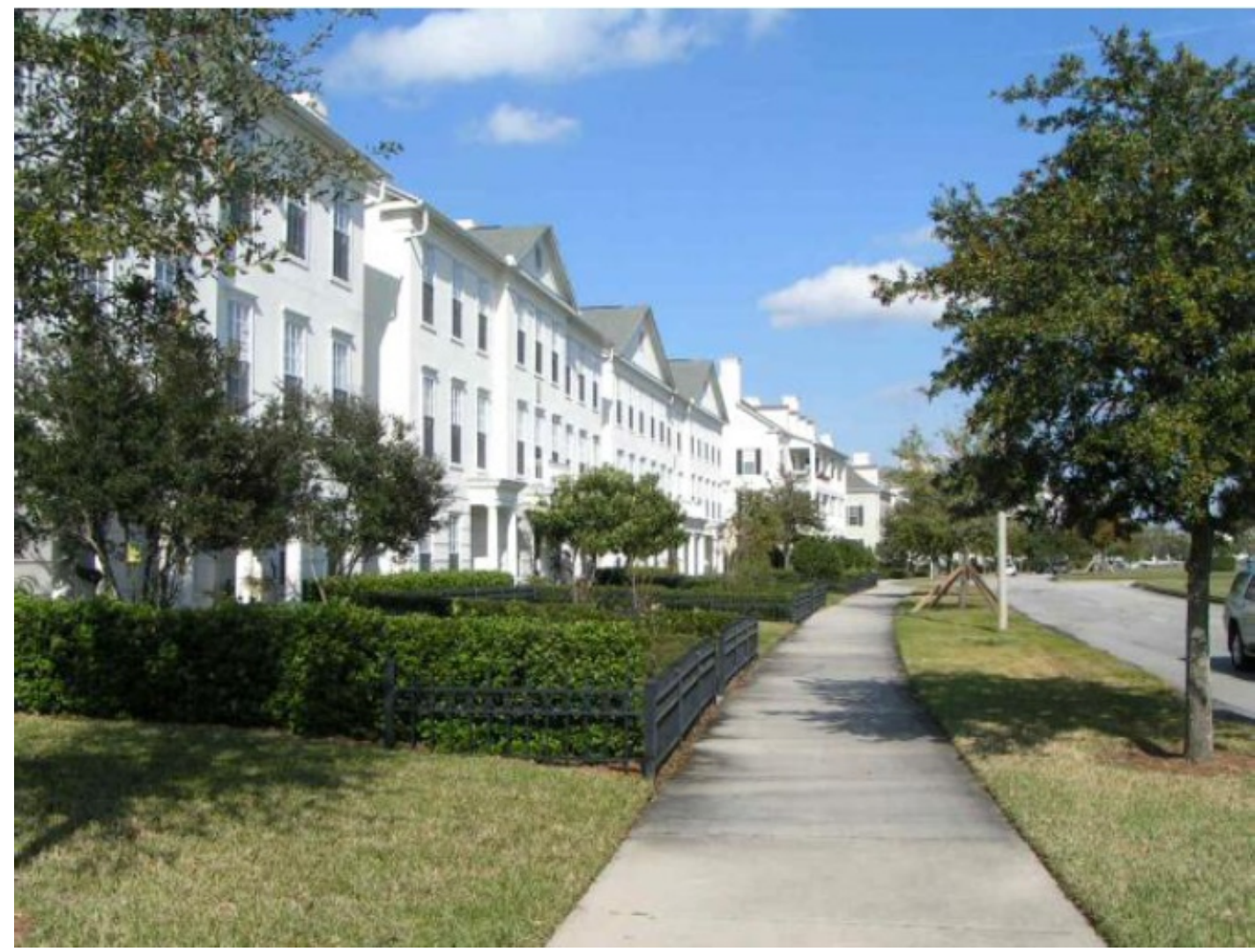

Fig. 9 Street curve showing a row of houses. Source: author 07.01.2010. 


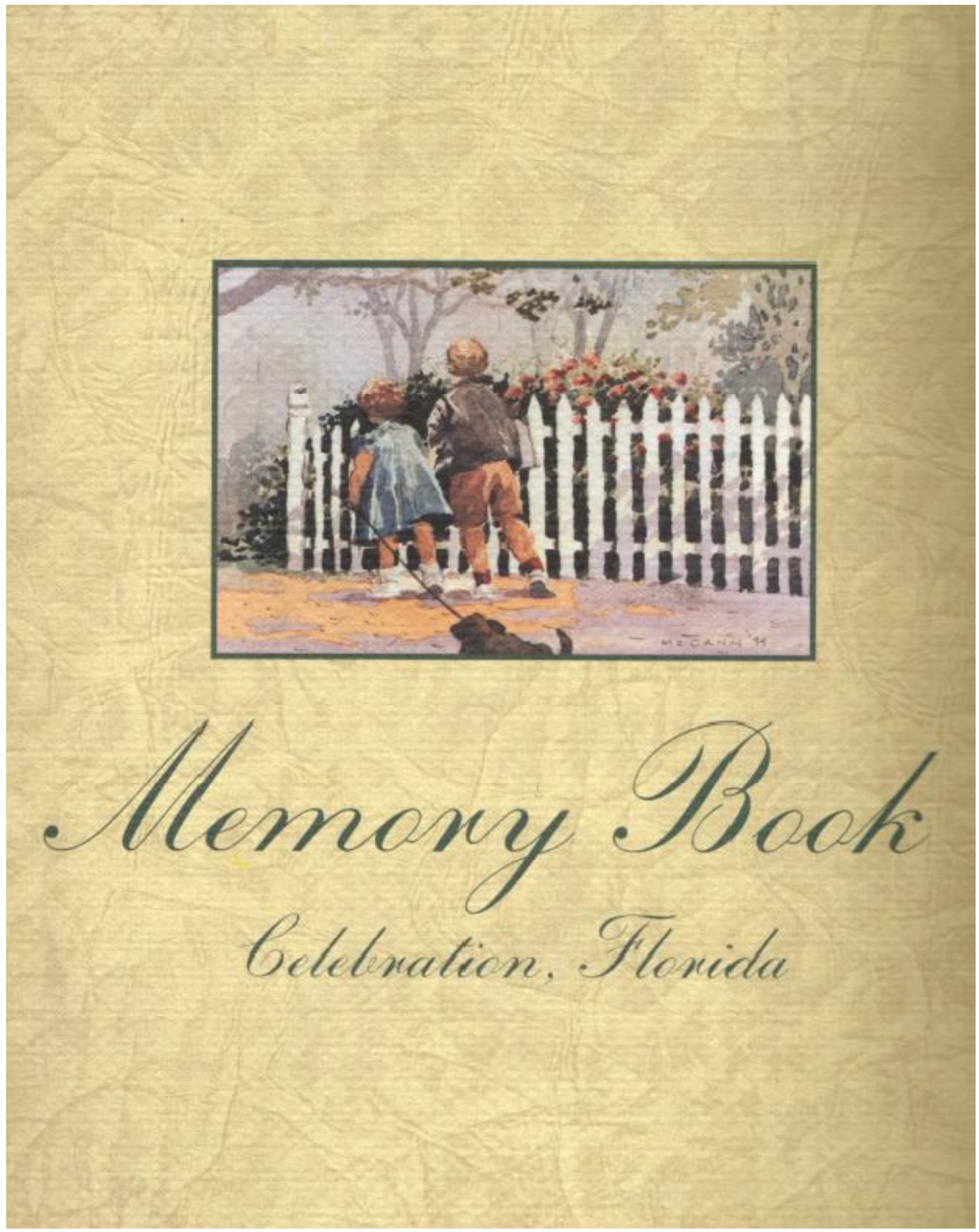

Fig. 10 To spread out the city's idea. Source: flyer, 2010. 


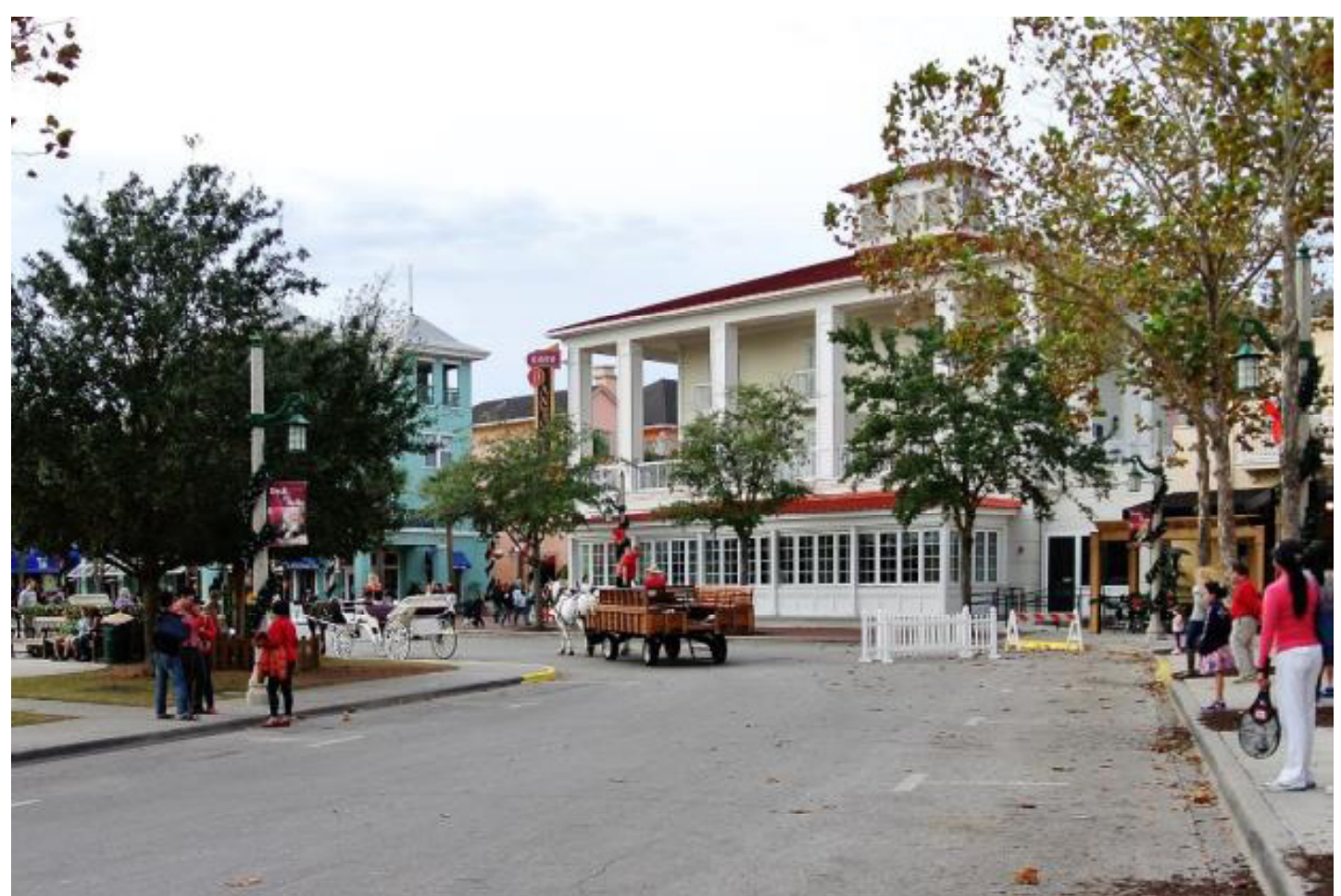

Fig. 11 Downtown, various building standards, a place for amenities. Source: author, 19.12.2014.

Coastal, Mediterranean and French (French).

Specialists in these styles have been consulted to provide detailed design criteria, including dimensions and qualities of the streets.

- Draw cuts showing the relationship of the facades of the houses with the space of the street.

- Accompany the study of traditional types by analyzing standard plants offered to the market by different entrepreneurs. The purpose is to know what is in the market to inform the needs program of the new types to be proposed.

- Adjust the needs program of each house and design according to the styles.

At Celebration, some houses were built on the same street, for demonstration and for comparing types of building volumes in the same neighborhood (Fig. 11).

\section{Final Assumptions: Celebration, New Urbanism and Smart Growth}

The New American Urbanism has the greater purpose of being a reaction to urban dispersion, criticizes Modern Urbanism and will seek in the cities of the first quarter of the last century the concepts of compactness and neighborhoods of mixed use, favoring the proximity of Jobs, services and reducing people's displacement. The movement brings together architects who are sensitive to traditional styles and those of modernist vision. It should be remembered that in the last two decades of the twentieth century, while organizing the ideas of the new urbanists, the Postmodern Architecture, attempts to revise traditional styles and regionalist derivatives grew in architecture. These are events that are related, both in the academic field and in professional practice. The affinity of principles related to these architects dealing with urbanism, landscaping and buildings, generated branches of New Urbanism with distinct emphases: Smart Growth, the umbrella covering urban and regional planning, Transit Oriented Development, related to the movements articulating cities (ex: Metro Orlando showed before) and the TND, Traditional Neighborhood Development, which in addition to the resumption of traditional urban types, extends to the styles of Architecture [7]. 
Celebration (1996), although not introduced by its designers as a manifestation of the New Urbanism movement, became known for this. The disclosure of this movement, whose initial landmark was the resort-town Seaside (1982), was expanded under the umbrella of Smart Growth. Concerning Celebration, the interest of people to be there is attributed to their project, by the criterion of rethinking the traditional way of life. This was a choice with a good repercussion in the urban design media [7]. Celebration very soon acquired the status of a place good to live-in or just to visit: near Orlando and with high environmental quality. Through the reasons of being a unique place, characterized by people enjoyment of living there, Celebration acquires a level of sustainability obtained by the social life aspects, being a place and not just a space.

The City of Celebration received several awards, among them: the NAIOP Excellence Awards, 1996, Development of the Year, as an urban venture; The 1997 Grand Project Excellence Award in the Large/Design/Civil-Surveying-Development Phase category as an urban infrastructure project: The 1998 Award of Excellence from the American Society of
Landscape Architects for the City Center Landscaping project, and in 2001 the Best New Community Award, Urban Land Institute's Award for Excellence. All this recognition is due to the quality and control that Disney usually imprints on its investments, in addition to the professional competence of the professionals involved.

\section{References}

[1] Barnett, J. 2003. Redesigning Cities, Principles, Practice, Implementation. Chicago: American Planning Association.

[2] Calthorpe, P., and Fulton, W. 2001. The Regional City. Washington, DC: Island Press.

[3] Martin, J. C. 1996. "Building Community." Urban Land March 55 (3): p.28-32, 55-56.

[4] Gindroz, R., and Robinson, R. 2004. The Architectural Pattern Book: A Tool for Building Great Neighborhoods. New York: W. W. Norton \& Company.

[5] Connellam, T. 1997. Inside the Magic Kingdom. New York: Peak Performance.

[6] CR\&P. n.d. www.thoughtco.com/celebration-floridadisneys-ideal-community-178231. Accessed June 1, 2018.

[7] Macedo, A. C. 2007. A Carta do Novo Urbanismo Americano. São Paulo: Vitruvius, Arquitextos (082.03). http://www.vitruvius.com.br/revistas/browse/arquitextos. Accessed June 1, 2018. 